\title{
Alih Fungsi Lahan di Kawasan Pariwisata Nusa Penida
}

\author{
Cange of Land Use in the Nusa Penida Tourism Area
}

\author{
Nyoman Sudipa ${ }^{1^{*}}$,Made Sudiana Mahendra ${ }^{2}$, Wayan Sandi Adnyana, \\ Ida Bagus Pujaastawa ${ }^{4}$
}

\author{
${ }^{1)}$ Fakultas Teknik Universitas Mahendradatta. Jalan Ken Arok 12-14, Denpasar. Bali. \\ ${ }^{2)}$ Program Studi Ilmu Lingkungan, Universitas Udayana, Jalan Sudirman Denpasar, Bali \\ ${ }^{3)}$ Program Studi Agroteknologi, Universitas Udayana Jalan Sudirman Denpasar, Bali \\ ${ }^{4)}$ Program Studi Ilmu Budaya, Universitas Udayana, Jalan P. Nias Denpasar, Bali \\ *corresponding author, email: nyoman_sudipa@yahoo.com
}

Manuscript received: 31-07-2020. Accepted: 28-09-2020

\begin{abstract}
ABSTRAK
Nusa Penida merupakan bagian dari Provinsi Bali yang terdiri dari tiga gususan pulau kecil yaitu Pulau Nusa Penida, Nusa Lembongan dan Nusa Ceningan dalam wilayah administratif Kecamatan Nusa Penida Kabupaten Klungkung. Perkembangan pariwisata di Nusa Penida telah meningkatkan akses pembangunan fisik dan sarana pendukung kawasan. Lompatan pembangunan sarana pariwisata mulai terasa dimulai pada tahun 2005 yaitu di Pulau Nusa Lembongan dan Nusa Ceningan. Pembangunan sarana pariwisata secara masif terjadi pada tahun 2015 sampai tahun 2019 semenjak dilaksanakan Festival Nusa Penida Tahun 2014. Wilayah pesisir dan pedalaman banyak dibangun akomodasi pariwisata yang tentunya menimbulkan alih fungsi lahan dan penyusutan lahan. Tujuan dari penelitian ini untuk mengetahui alih fungsi lahan dari tahun 2003 sampai tahun 2019 dengan menggunakan metode analisis tumpang susun peta google dan peta yang bersumber dari citra quick bird. Alih fungsi lahan di Kawasan Nusa Penida dari tahun 2003 sampai dengan tahun 2019 mencapai 164.84 ha atau laju alih fungsi lahan yang terjadi di Kawasan Nusa Penida adalah sebesar $0.85 \%$.
\end{abstract}

Kata kunci : akomodasi; laju; pembangunan; penyusutan

\begin{abstract}
Nusa Penida is part of the Province of Bali which consists of three small islands, namely Nusa Penida Island, Nusa Lembongan and Nusa Ceningan within the administrative area of Nusa Penida District, Klungkung Regency. The development of tourism in Nusa Penida has increased access to physical development and supporting facilities for the region. The leap of development of tourism facilities began to be felt starting in 2005, namely on the islands of Nusa Lembongan and Nusa Ceningan. The development of massive tourism facilities took place in 2015 until 2019 since the 2014 Nusa Penida Festival was held. Many coastal and inland areas were built with tourism accommodation, which naturally led to land conversion and land depreciation. The purpose of this study was to determine land use change from 2003 to 2019 using the overlapping analysis method of Google maps and maps
\end{abstract}


derived from quick bird imagery. Transfer of land functions in the Nusa Penida Region from 2003 to 2019 reached 164.84 ha or the rate of land use change that occurred in the Nusa Penida Region was $0.85 \%$.

Keywords: accommodation; rate; construction; depreciation

\section{PENDAHULUAN}

Pembangunan pariwisata dapat menimbulkan penurunan terhadap kualitas lingkungan. Dengan dibangunnya sarana pariwisata dapat menimbulkan alih fungsi lahan kosong menjadi lahan terbangun. Pembangunan pariwisata harus mempertimbangkan aspek-aspek ekologis seperti ketersedian air bersih, pembuangan sampah, pencemaran lingkungan, terganggunya daya tampung lingkungan, bahkan sampai dengan status kepemilikan tanah untuk pembangunan rumah dan permasalahan kerentanan kebencanaan. (Khrisnamurti et al., 2016).

Alih fungsi lahan lahan adalah berubahnya satu penggunaan lahan ke penggunaan lainnya. Hal ini umumnya terjadi di daerah yang sedang berkembang secara ekonomi seperti di Kawasan Pariwisata Nusa Penida. Faktor yang mempengaruhi alih fungsi lahan adalah bertambahnya populasi penduduk, perkembangan teknologi, pertumbuhan ekonomi, pendidikan dan kebudayaan, selera dan nilai serta perubahan sikap karena perkembangan usia (Ardi et al., 2016). Dampak terhadap tanah berupa alih fungsi lahan yang diakibatkan oleh pembangunan infrastruktur penunjang pariwisata, pembangunan akomodasi pariwisata dan fasilitas pendukungnya, alih fungsi lahan akibat dibuatnya permukiman baru, dan alih fungsi jalur hijau dan keterdesakan antivitas petani rumput laut dan nelayan karena penguasaan akses pantai karena kepentingan pariwisata.

Hasil penelitian ini memberikan gambaran mengenai alih fungsi lahan yang terjadi di Kawasan Pariwisata Nusa Penida dari tahun 2003 sampai tahun 2019 dan memberikan informasi desa atau wilayah mana saja yang mengalami peningkatan pembangunan atau alih funsi lahan. Penelitian ini dapat memberikan gagasan baru tentang pengelolaan kawasan di masa mendatang jika pariwisata terus bertumbuh di Kawasan Pariwisata Nusa Penida dan memberikan batasan-batasan dalam pembangunan akomodasi dan fasilitas penunjang pariwisata yang bisa dituangkan dalam kebijakan pemerintah daerah.

\section{METODOLOGI PENELITIAN}

Bahan penelitian menggunakan peta Google dan peta yang bersumber dari Citra Satelit Quick Bird yang di peroleh dari Badan Geospasial. Selanjunya peta Google Tahun 2003 dan Peta dari Citra Satelit Quick Bird Tahun 2019 dilakukan digitasi secara detail yang menyangkut bangunan rumah akomodasi pariwisata dan gedung beserta halamannya. Metode analisis yang dipergunakan adalah analisis spasial dengan menggunakan teknik operasi tumpang-susun yang dilakukan menumpangsusunkan peta penggunaan lahan pada rona awal dengan peta penggunaan lahan tahun terakhir. Menurut Astuti (2011), perhitungan laju alih fungsi lahan digunakan persamaan alih fungsi lahan. Laju alih fungsi lahan dapat ditentukan dengan cara menghitung laju alih fungsi lahan secara parsial. Laju alih fungsi lahan secara parsial dapat dijelaskan sebagai berikut: 
$\mathrm{V}=\frac{L t-L t-1}{L t-1} \times 100 \%$

Keterangan:

$\mathrm{V}=$ Laju alih fungsi lahan $(\%)$

Lt $\quad=$ Luas lahan tahun ke $\mathrm{t}(\mathrm{ha})$

Lt-1 = Luas lahan tahun sebelum $\mathrm{t}(\mathrm{ha})$

Laju alih fungsi lahan dapat ditentukan melalui selisih antara luas lahan tahun ke $\mathrm{t}$ dengan luas lahan tahun sebelum $\mathrm{t}(\mathrm{t}-1)$. Kemudian dibagi dengan luas tahun sebelum $\mathrm{t}(\mathrm{t}-1)$ tersebut dikalikan 100 persen. Hal ini dilakukan juga pada tahun-tahun berikutnya sehingga diperoleh laju alih fungsi lahan setiap tahun. Nilai $\mathrm{V}<0$ berarti bahwa luas lahan tersebut mengalami alih fungsi.

\section{HASIL DAN PEMBAHASAN}

Luas wilayah Kecamatan Nusa Penida adalah 202,84 km² atau 20.284 ha. Untuk menghitung laju alih fungsi lahan di Kawasan Pariwisata Nusa Penida dibutuhkan peta rupa bumi dan citra satelit. Adapun rona awal peta yang dipergunakan adalah peta google tahun 2003 dengan citra Satelit Quick Bird yang bersumber dari Badan Informasi Geospasial tahun 2019. Alih fungsi lahan difokuskan pada alih fungsi untuk pemanfaatan lahan sebagai pemukiman (rumah, kantor dan akomodasi pariwisata) beserta pemanfaatan untuk halaman. Sebelum dilakukan over lay, kedua peta ini didigitasi secara detail untuk memastikan luas pemukiman. Pemukiman dalam hal ini adalah rumah penduduk, kantor dan akomodasi pariwisata.

\section{Pemukiman Berdasarkan Pola Ruang}

Pemukiman berdasarkan pola ruang menggunakan peta google skala 1:25.000 tahun 2003. Untuk mengetahui detail kawasan terbangun di Nusa Penida dilakukan dengan melakukan digitasi peta dan pemeriksaan secara detail untuk mengetahui kondisi dan sebaran pemukiman pada tahun 2003. Pada tahun 2003 sebaran permukiman terlihat di sekitar pesisir utara Nusa Penida, pesisir barat Nusa Penida, sebagian pesisir barat Nusa Lembongan dan sebagian pesisir utara Nusa Ceningan. Dibagian lain Nusa Penida tersebar titik pemukiman tidak merata dan pada bagian tengah Nusa Penida dan timur yang terlihat sangat sedikit ada titik pemukiman. Pada tahun 2003 investasi pariwisata belum masuk ke Nusa Penida, hanya berupa kunjungan kecil dan terpusat di wilayah Desa Jungutbatu dan Desa Lembongan. Pembangunan sarana pemukiman berkaitan erat dengan kondisi ekonomi Nusa Penida saat itu seperti terlihat pada Gambar 1. 


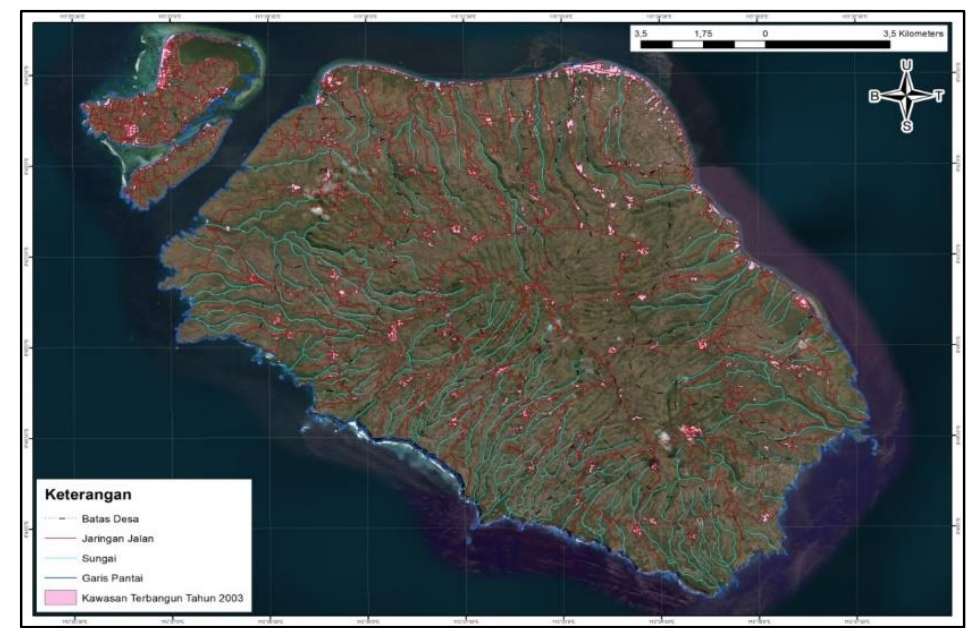

Gambar 1. Kawasan Terbangun Berdasarkan Peta Google 2003

Terlihat dari sebaran kemiskinan yang cukup tinggi di Nusa Penida pada tahun 2005, dimana 50\% kemiskinan Kabupaten Klungkung ada di Nusa Penida dan mahalnya biaya membangun rumah karena sebagian besar material bangunan didatangkan dari Pulau Bali yang berdampak pada tingginya biaya transportasi (Sudipa, 2014). Apalagi pada saat itu hanya mengunakan perahu tradisional dan belum ada angkutan laut modern seperti sekarang sehingga kemampuan masyarakat untuk membangun rumah sangat rendah di samping beban ekonomi biaya tinggi. Dari hasil perhitungan luas pemukiman di Nusa Penida dengan menggunakan peta pemukiman berdasarkan peta pola ruang tahun 2003 tercatat luas pemukiman seluas 762,78 ha atau 3,76 persen dari seluruh luas wilayah Nusa Penida. Luas wilayah Nusa Penida yang tersisa setelah dikurangi luas pemukiman adalah 19.521 ha seperti terlihat pada Gambar 2.

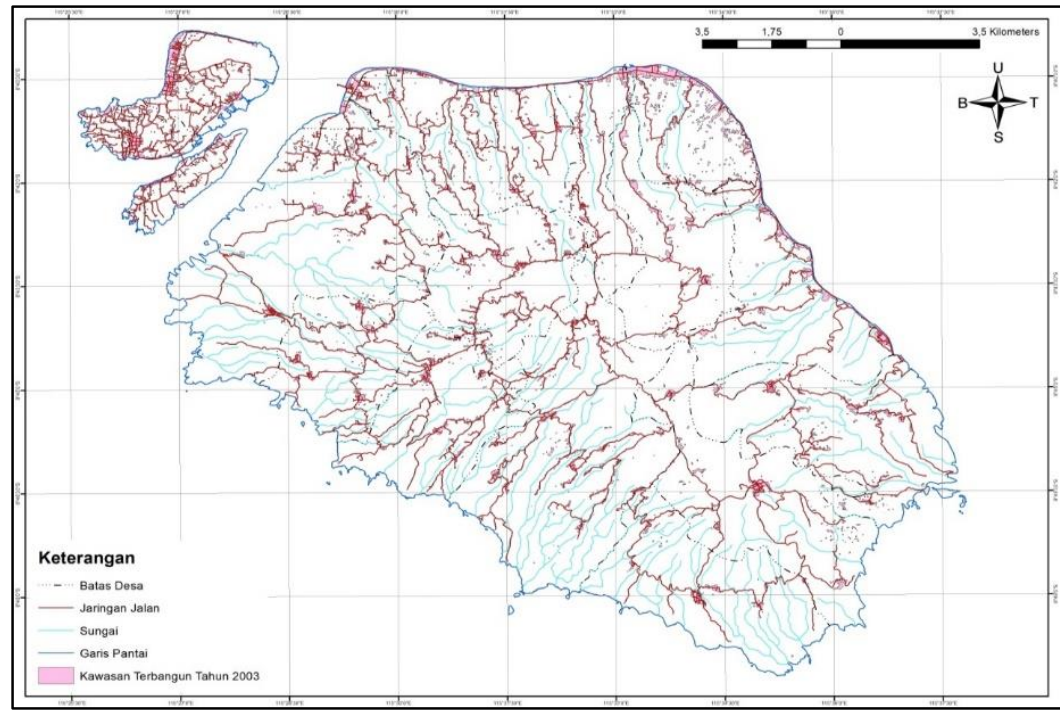

Gambar 2 Kawasan Terbangun Berdasarkan Hasil Digitasi

\section{Kawasan Terbangun Tahun 2019}

Peta kawasan terbangun menggunakan citra Satelit Quick Bird yang bersumber dari Badan Informasi Geospasial tahun 2019 dan dilakukan digitasi. Dari peta kawasan terbangun tahun 
2019 terlihat sebaran pemukiman yang sudah meluas dan hampir merata ke seluruh bagian Nusa Penida. Kondisi ini disebabkan oleh masifnya pembangunan akomodasi pariwisata dan masifnya pembangunan rumah tinggal masyarakat seperti terlihat pada Gambar 3.

Hal ini disebabkan karena tumbuhnya ekonomi di Nusa Penida akibat berkembangnya pariwisata dan meningkatnya tingkat kunjungan wisatawan ke Nusa Penida pada 5 tahun terakhir. Lapangan kerja terbuka di Nusa Penida. Hampir sebagian besar masyarakat produktif bekerja di sektor pariwisata. Setiap hari masyarakat sibuk membangunan akomodasi pariwisata dan membangun pemukiman baru sebagai bentuk aktualisasi pendapatan yang meningkat.

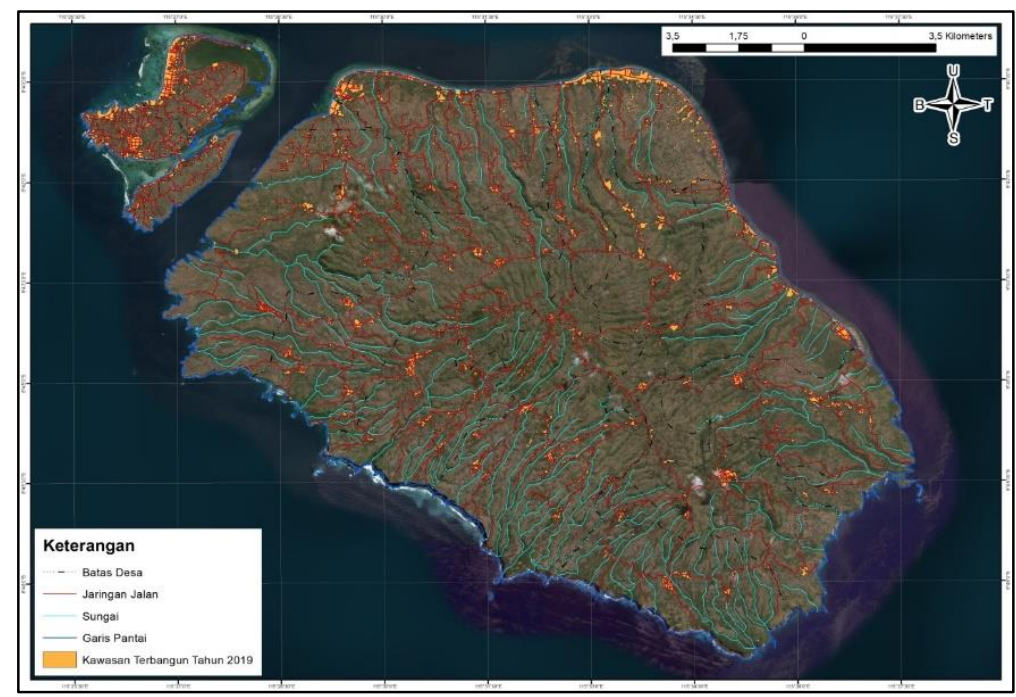

Gambar 3. Kawasan Terbangun Tahun 2019 dari Citra Satelit Quick Bird

Dari hasil perhitungan luas kawasan terbangun di Nusa Penida dengan menggunakan hasil digitasi peta bersumber dari Citra Satelit Quick Bird tahun 2019 yang bersumber dari Badan Informasi Geospasial tercatat luas kawasan terbangun adalah 927,62 ha atau 4,57 persen dari seluruh luas wilayah Nusa Penida. Luas wilayah Nusa Penida yang tersisa setelah dikurangi luas kawasan terbangun adalah 19.356 ha seperti terlihat pada Gambar 4.

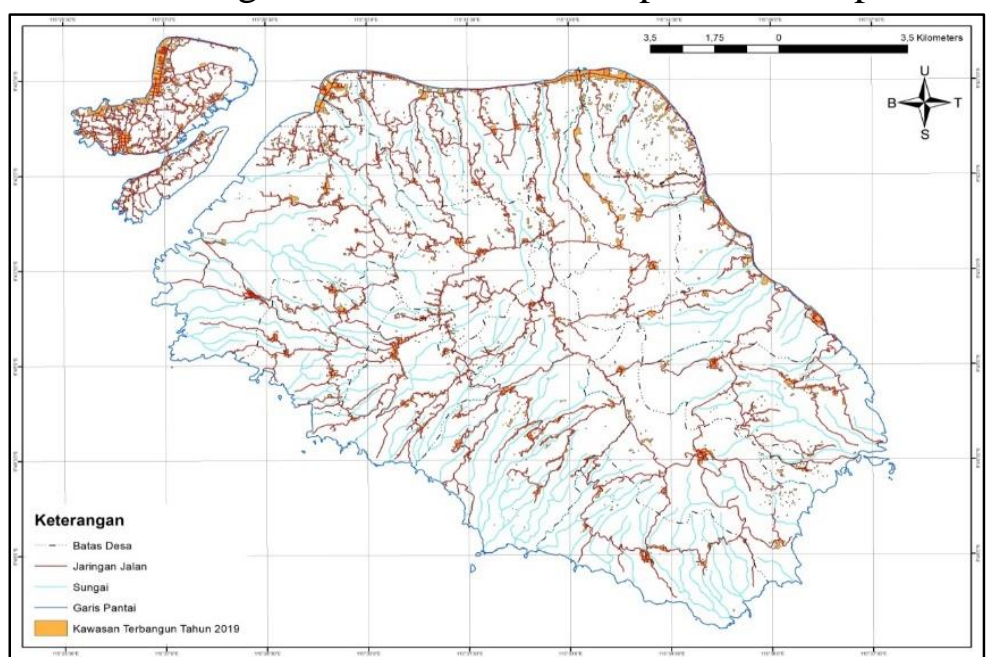

Gambar 4. Kawasan Terbangun Tahun 2019 Hasil Digitasi bersumber dari Citra Satelit Quick Bird 


\section{Laju Alih Fungsi Lahan}

Berdasarkan hasil digitasi peta google dan peta hasil digitasi Citra Satelit Quick Bird tahun 2019 yang bersumber dari Badan Informasi Geospasial dilakukan overlay atau tumpang susun untuk melihat pola sebaran dan perkembangan pemukiman di Nusa Penida. Dari Gambar 5 dan Gambar 6 terlihat sebaran pemukiman sedemikian masif terutama di Pulau Nusa Lembongan dan Ceningan. Sedangkan di Pulau Nusa Penida sebaran pemukiman merayap naik dari Desa Ped, Toyapakeh dan Desa Sakti dan terlihat titik-titik pemukiman baru yang terjadi hampir di setiap desa di Pulau Nusa penida. Alih fungsi lahan mencapai 164.84 ha. Hasil perhitungan luas kawasan terbangun berdasarkan peta google tahun 2003 dan peta Cira Satelit Quick Bird yang bersumber dari Badan Informasi Geospasial tahun 2019, maka laju alih fungsi lahan di Nusa Penida adalah 19.521 dikurangi 19.356 dibagi 19.356 dikali 100\%. Laju alih fungsi lahan di Nusa Penida dari tahun 2003 sampai tahun 2019 atau dalam kurun waktu 16 tahun sebesar $0.85 \%$.

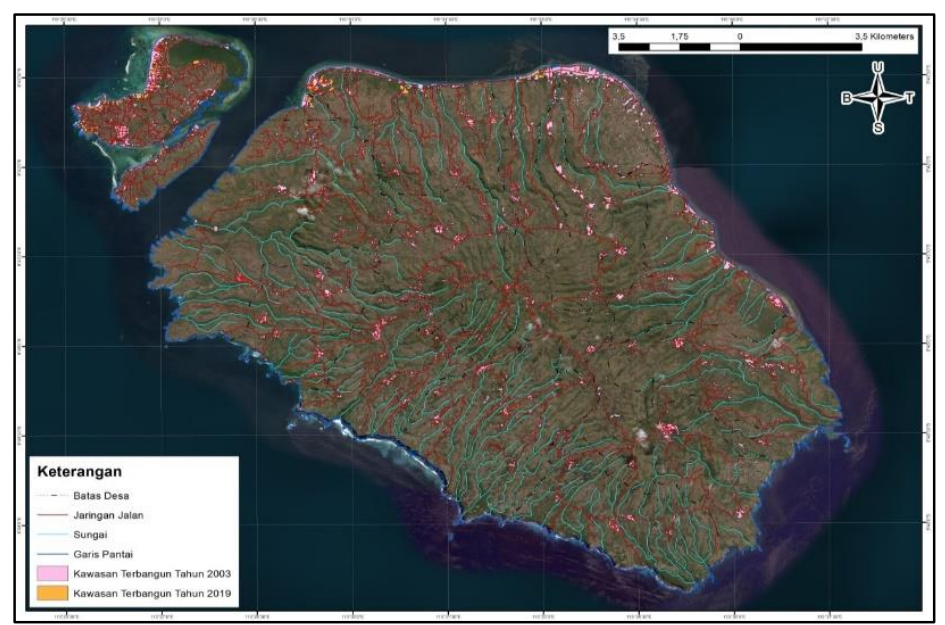

Gambar 5. Overlay Peta Google Tahun 2003 dan Peta Citra Satelit Quick Bird Tahun 2019

Sebagai bahan perbandingan alih fungsi lahan di Kawasan Pariwisata Nusa Penida, pada tahun 2003 jumlah hotel atau villa di Kawasan Pariwisata Nusa Penida hanya berjumlah 16 unit yang tersebar di Pulau Nusa Lembongan dan jumlah restoran hanya 7 unit yang semuanya tersebar di Pulau Nusa Lembongan (BPS Provinsi Bali, 2018). Pada 4 tahun terakhir pembangunan akomodasi dan fasilitas penunjang pariwisata meningkat dengan pesat yang didominasi oleh investor lokal Nusa Penida. Pada akhir 2018 tercatat 3000 lebih kamar telah terbangun. 


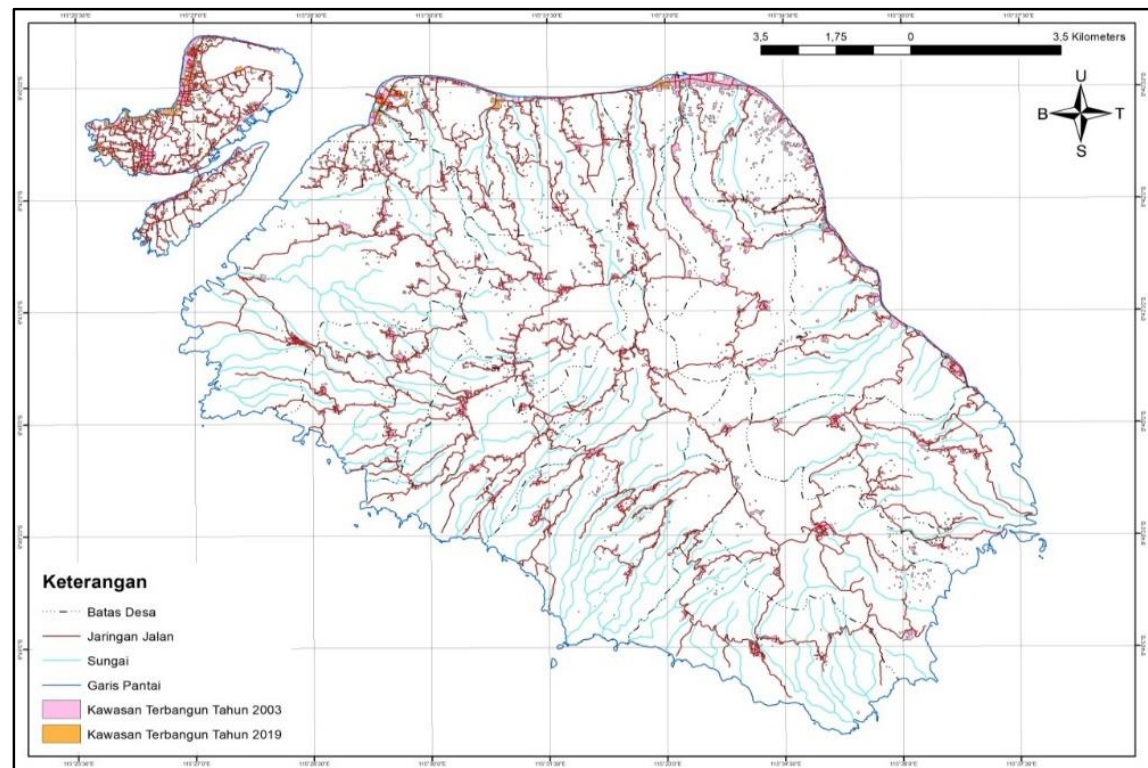

Gambar 6. Overlay Hasil Digitasi Peta Google Tahun 2003 dan Citra Satelit Quick Bird Tahun 2019

Berdasarkan hasil survei yang dilakukan pada akhir tahun 2018 yang dipublikasi pada tahun 2019 menunjukkan bahwa akomodasi dan atraksi pariwisata telah berkembang dengan pesat meliputi:

1. Akomodasi pariwisata sebanyak 313 baik berupa villa maupun hotel beserta fasilitas pendukung.

2. Sarana transportasi wisata angkutan laut sebanyak 32 .

3. Bar sebanyak 30.

4. Restoran/rumah makan sebanyak 131 buah.

5. Spa sebanyak 17.

6. Diving sebanyak 25.

7. Water sport sebanyak 14.

8. Cruise 18.

Penggunaan lahan merupakan kegiatan pemanfaatan ruang yang telah ada, dan dapat diasumsikan apabila tidak ada pelanggaran pemanfaatan ruang yang berarti, deliniasi pemanfaatan ruang ini seluruhnya merupakan kawasan potensial. Pelanggaran terhadap rencana tata ruang yang menimbulkan permasalahan serius dapat dilakukan penyesuaian atau kawasan potensialnya berubah menjadi lindung atau ruang terbuka hijau. Kondisi seperti ini dapat dijumpai pada aktivitas atau penggunaan lahan untuk kegiatan perumahan, kegiatan pariwisata pada beberapa blok yang telah ditetapkan sebagai jalur hijau. Berdasarkan hasil pengamatan di lapangan menunjukkan bahwa implementasi kebijakan pola ruang terhadap pengembangan kawasan strategis pariwisata di Nusa Penida diketahui bahwa rencana pola ruang yang dijabarkan dalam peraturan daerah tidak bisa digunakan sebagai acuan lebih detail dalam pelaksanaan pembangunan di Nusa Penida. Hal ini karena kebijakan yang ada berupa arahan secara umum tidak mengatur secara detail pola ruang yang ada. 
Desakan kebutuhan lahan untuk pembangunan begitu deras di Kawasan Pariwisata Nusa Penida, sedangkan di satu sisi luas lahan tidak pernah bertambah. Nusa penida sebagai penghasil produk-produk pertanian, ternak dan rumput laut keberadaannya mulai terdesak karena pertumbuhan pembangunan fasilitas pariwisata. Hal ini akan berdampak kepada menurunnya daya dukung pangan. Manfaat dari adanya lahan pertanian dan budidaya rumput laut pertahankan, karena akan mengganggu konservasi lahan pertanian dan lingkungan (Dewi et al, 2013).

Faktor utama meningkatnya alih fungsi lahan adalah laju pertumbuhan penduduk dan migrasi penduduk yang menyebabkan meningkatnya kebutuhan untuk pemukiman dan fasilitas penunjang lainnya, pertubuhan ekonomi di suatu wilayah yang disertai dengan aktivitas pembangunan, mobilasi tenaga kerja yang memerlukan pemukiman baru dan fasilitas pendukung wilayah seperti infrastruktur (Janah et al., 2017). Lebih lanjut alih fungsi lahan mempunyai dampak terhadap alih pekerjaan masyarakat yang disebabkan oleh berkurangnya lahan pertanian, dimana dari pekerjaan petani menjadi buruh bangunan atau pekerjaan lainnya sesuai dengan bidang pekerjaan yang ada, perdiaan pangan keluarga menjadi menurun karena berubahnya pemanfaatan lahan dan berkurangnya fungsi lingkungan akibat daya dukungnya menurun.

Pola pembangunan di Nusa Penida sebaiknya memperhatikan kemampuan lahan, karena proses pembangunan yang tidak memperhatikan kelas kemampuan lahan akan menimbulkan akibat buruk bagi lingkungan. Daya dukung lahan di Nusa Penida yang terbatas bahkan defisit perlu menjadi faktor yang sangat diperhatikan, apalagi kalau membangun pada lahan yang dimanfaatkan untuk kepentingan pertanian untuk mendukung ketahanan pangan dan lahan berfungsi sebagai hutan lindung, maupun pada lokasi yang rawan longsor atau erosi. Perlu kehati-hatian dalam menerapkan kebijakan di Nusa Penida. Sumber pendapatan utama rumah tangga di Nusa penida berasal dari usaha tani, bahwa rumah tangga yang tidak melakukan alih fungsi lahan mempunyai peluang lebih besar untuk mengakses pangan. Pendapatan usaha tani pada rumah tangga yang tidak melakukan alih fungsi lahan berpengaruh positif terhadap pendapan rumah tangga, maka pemerintah hendaknya menghentikan alih fungsi lahan atau mengendalikan alih fungsi lahan. Upaya pengendalian ini tidak saja pada pembuatan aturan saja, namun juga mengawal dan memonitor pelaksanaan peraturan tersebut untuk menjamin tidak terjadinya alih fungsi lahan. Pemberian insentif pada rumah tangga petani yang mengusahakan budidaya tani di lahan produktif perlu juga diupayakan, sehingga mereka tidak mengalihfungsikan lahannya (Purwaningsih et al., 2015).

Pembatasan pembangunan permukiman dan akomodasi perlu ditetapkan dalam perencanaan tata ruang kawasan untuk menghindari semakin meluasnya pembangunan dan alih fungsi lahan di Nusa Penida. Pertumbuhan pembangunan akomodasi perlu dikendalikan agar tidak merambah ruang-ruang untuk peruntukan permukiman, pertanian, dan hutan. Perlu dibuat batas-batas yang jelas dalam penataan ruang. Pesatnya pertumbuhan pemukiman akan berdampak pada peningkatan penggunaan sumber daya lingkungan (air dan lahan). Salah satu dampak yang terlihat di lapangan adalah masalah sampah. Meningkatnya pendapatan masyarakat karena perkembangan pariwisata meningkatkan 
konsumsi masyarakat, kemudian menimbulkan sampah. Masalah lainnya yaitu meningkatnya polusi dan konflik social (Sudipa et al, 2020).

Salah satu permasalahan krusial lainnya yang dihadapi adalah menyangkut pemanfaatan sempadan pantai. Dalam Peraturan Daerah No. 16 Tahun 2009 tentang Rencana Tata Ruang Wilayah Provinsi Bali dan Peraturan Daerah No. 1 Tahun 2013 tentang Tata Ruang Wilayah Kabupaten Klungkung, menyatakan bahwa sempadan pantai 100 meter dari pasang tertinggi. Ruang-ruang ekonomi lebih banyak berada di daerah pesisir pantai, karena pantai Nusa Penida seluruhnya berisi pasir putih yang tentu memiliki daya tarik tersendiri untuk pariwisata. Kenyataan di lapangan menunjukan bahwa areal sempadan 100 meter telah terbangun untuk akomodasi pariwisata. Perlu dilakukan studi khusus untuk mengatur sempadan sesuai dengan tipologi pantai sehingga masalah perijinan di wilayah pesisir bisa ditangani dengan baik. Dalam penanggulangan pelanggaran pembangunan pemerintah sebaiknya melakukan pembinaan, pengawasan dan memberikan sangsi yang tegas terhadap para pelaku pelanggaran.

\section{KESIMPULAN}

Luas pemukiman pada tahun 2003 seluas 762.78 ha atau 3.76 persen dari seluruh luas wilayah Nusa Penida. luas kawasan terbangun adalah 927,62 ha atau 4.57 persen dari seluruh luas wilayah Nusa Penida. alih fungsi lahan di Kawasan Nusa Penida dari tahun 2003 sampai dengan tahun 2019 mencapai 164.84 ha atau laju alih fungsi lahan yang terjadi di Kawasan Nusa Penida adalah sebesar $0.85 \%$.

\section{Ucapan Terimakasih}

Penulis mengucapkan terimakasih kepada Bidang tata Ruang Dinas Pekerjaan Umum Kabupaten Klungkung yang telah memfasilitasi peta dari Badan Informasi Geospasial dan rekan tim survei lapangan yang telah bekerja keras di lapangan untuk mencocokkan hasil digitasi dan kondisi sesungguhnya di lapangan.

\section{DAFTAR PUSTAKA}

Ardi, R. D., Agustina, I. H. 2016. Kajian Alih Fungsi Lahan Pertanian terhadap Swasembada Beras di Kabupaten Bekasi; Prosiding Perencanaan Wilayah dan Kota: 2 (1): 121-127.

Astuti, D. 2011. "Keterkaitan Harga Lahan Terhadap Laju Konversi Lahan Pertanian di Hulu Sungai Ciliwung Kabupaten Bogor" (skripsi). Bogor: Institut Pertanian Bogor.

BPS Provinsi Bali, 2018. Bali Dalam Angka 2018. Denpasar

Dewi, N., K, Rudiarto, I. 2013. Identifikasi Alih Fungsi Lahan Pertanian dan Kondisi Sosial Ekonomi Masyarakat Daerah Pinggiran di Kecamatan Gunungpati Kota Semarang; Jurnal Wilayah dan Lingkungan: 1 (2): 175-188

Janah, R., Eddy, B. T., Dalmiyatun, T. 2017. Alih Fungsi Lahan Pertanian dan Dampaknya terhadap Kehidupan Penduduk di Kecamatan Sayung Kabupaten Demak; Jurnal Sosial Ekonomi Pertanian: 1 (1): 1-10. 
Krisnamurti, Utami, H., Darmawan, R. 2016. Dampak Pariwisata terhadap Lingkungan di Pulau Tidung Kepulauan Seribu; Jurnal Kajian: 21 (3): 257-273.

Peraturan Daerah No. 16 Tahun 2009 tentang Rencana Tata Ruang Wilayah Provinsi Bali Peraturan Daerah No. 1 Tahun 2013 tentang Tata Ruang Wilayah Kabupaten Klungkung

Purwaningsih, Y., Sutomo. Istiqomah, N. 2015. Analisis Dampak Alih Fungsi Lahan terhadap Tingkat Ketahanan Pangan Rumah Tangga Petani di Karanganyar, Jawa Tengah; Jurnal Agraris: 1 (2): 1-11.

Sudipa, N., Mahendra, M. S., Adnyana, W. S., Pujaastawa, I. B. 2020. Model Pengelolaan Lingkungan di Kawasan Pariwisata Nusa Penida, Bali; Jurnal Ecotrophic: 14(1):113

Sudipa, N. 2014; Paradox of Poverty in Village Ubud: E-journal Cultural Studies: 7 (3): 16. 